University of Nebraska - Lincoln

DigitalCommons@University of Nebraska - Lincoln

2005

\title{
The Value of Agricultural Wetlands as Invertebrate Resources for Wintering Shorebirds
}

Oriane W. Taft

U.S. Geological Survey, oriane_taft@usgs.gov

Susan M. Haig

U.S. Geological Survey, Susan_Haig@usgs.gov

Follow this and additional works at: https://digitalcommons.unl.edu/usgsstaffpub

Taft, Oriane W. and Haig, Susan M., "The Value of Agricultural Wetlands as Invertebrate Resources for Wintering Shorebirds" (2005). USGS Staff -- Published Research. 663.

https://digitalcommons.unl.edu/usgsstaffpub/663

This Article is brought to you for free and open access by the US Geological Survey at DigitalCommons@University of Nebraska - Lincoln. It has been accepted for inclusion in USGS Staff -- Published Research by an authorized administrator of DigitalCommons@University of Nebraska - Lincoln. 


\title{
The value of agricultural wetlands as invertebrate resources for wintering shorebirds
}

\author{
Oriane W. Taft ${ }^{\text {a,b,*}}$, Susan M. Haig ${ }^{\text {a }}$ \\ ${ }^{\text {a } U S G S ~ F o r e s t ~ a n d ~ R a n g e l a n d ~ E c o s y s t e m ~ S c i e n c e ~ C e n t e r, ~ D e p a r t m e n t ~ o f ~ F i s h e r i e s ~ a n d ~ W i l d i f e, ~}$ \\ Oregon State University, 3200 SW Jefferson Way, Corvallis, OR 97331, USA \\ ${ }^{\mathrm{b}}$ Department of Fisheries and Wildlife, Oregon State University, Corvallis, OR 97331, USA \\ Received 13 July 2004; received in revised form 4 April 2005; accepted 18 April 2005 \\ Available online 4 June 2005
}

\begin{abstract}
Agricultural landscapes have received little recognition for the food resources they provide to wintering waterbirds. In the Willamette Valley of Oregon, modest yet significant populations of wintering shorebirds (Charadriiformes) regularly use hundreds of dispersed wetlands on agricultural lands. Benthic invertebrates are a critical resource for the survival of overwintering shorebirds, yet the abundance of invertebrate resources in agricultural wetlands such as these has not been quantified. To evaluate the importance of agricultural wetlands to a population of wintering shorebirds, the density, biomass, and general community composition of invertebrates available to birds were quantified at a sample of Willamette Valley sites during a wet (1999-2000) and a dry winter (2000-2001). Invertebrate densities ranged among wetlands from 173 to 1925 (mean \pm S.E.: $936 \pm 106)$ individuals $/ \mathrm{m}^{2}$ in the wet winter, and from 214 to $3484(1028 \pm 155)$ individuals $/ \mathrm{m}^{2}$ in the dry winter. Total invertebrate estimated biomass among wetlands ranged from 35 to 652 (mean \pm S.E.: $364 \pm 35$ ) $\mathrm{mg} / \mathrm{m}^{2}$ in the wet winter, and from 85 to $1405(437 \pm 62) \mathrm{mg} / \mathrm{m}^{2}$ in the dry winter. These estimates for food abundance were comparable to that observed in some other important freshwater wintering regions in North America.
\end{abstract}

Published by Elsevier B.V.

Keywords: Invertebrate abundance; Dunlin; Killdeer; Oligochaetes; Wetland landscape; Wintering waterbirds

\section{Introduction}

For shorebirds and many other waterbirds, invertebrate food resources provided by a region are critical for overwinter survival (e.g., Senner and

\footnotetext{
* Corresponding author. Tel.: +1 5417507390 ; fax: +1 5417588806 .

E-mail address: oriane_taft@usgs.gov (O.W. Taft).
}

Howe, 1984) and can be an important indicator of landscape quality. Gaining knowledge of typical invertebrate resources available within wetlands is an important first step towards determining potential carrying capacity of a region for waterbirds and for assessing levels of enhancement and restoration needed to support target populations (e.g., Anderson and Smith, 1999; Augustin et al., 1999). However, research evaluating regional invertebrate resources 
has primarily focused on the managed or natural wetlands of an area. Aside from regions dominated by flooded rice or soybean fields (e.g., Fasola and Ruiz, 1997; Twedt et al., 1998; Elphick and Oring, 1998, 2003), agricultural wetland landscapes have received little recognition for their current and potential value to wintering waterbirds.

The Willamette Valley of Oregon ("Valley"), USA, is one such agricultural landscape whose current and potential importance to waterbirds has only recently been acknowledged (Sanzenbacher and Haig, 2002a,b; Taft and Haig, in press). Although most historical wetlands of the Valley have been lost or highly altered by agriculture (Taft and Haig, 2003), current estimates for wintering waterbird populations are nonetheless sizeable (Nehls, 1994; Sanzenbacher and Haig, 2002a,b; Taft and Haig, 2003; R. Trost, U.S. Fish and Wildlife Service, personal communication). Such numbers support recognizing the Valley as a wetland complex of at least regional importance to shorebirds (Myers et al., 1987) within the Western Hemisphere Shorebird Reserve Network (Brown et al., 2001). Whereas waterfowl primarily use the few protected refuges of the Valley, shorebirds principally rely on the thousands of hectares of privately-owned agricultural wetlands ('palustrine emergent-farmed wetlands' of Cowardin et al., 1979; Sanzenbacher and Haig, 2002a,b; Taft and Haig, in press). Representing the legacy of historical Valley wetlands, these are flooded farmlands that annually emerge with the accumulation of winter rains on native hydric soils (Taft and Haig, 2003; Taft et al., 2004).

The Valley was used as a model to explore the relative value of a complex of agricultural wetlands as a wintering landscape for shorebirds and other waterbirds. Objectives of the study were to quantify benthic invertebrate density, biomass, and community composition during two different winters (wet and dry) at a sample of agricultural wetlands potentially used by shorebirds and to assess intersite variation in these measures. This paper then evaluates how invertebrate resources of these wetlands compare to other significant wintering regions, and assesses the potential for augmenting invertebrate productivity in regions like the Valley through local enhancement and restoration.

\section{Methods and study area}

\subsection{Study area}

The greater Willamette Valley encompasses $9100 \mathrm{~km}^{2}$ of lowland plains (Clark et al., 1991; Benner and Sedell, 1997) within Oregon's Willamette Basin, a 29,000 $\mathrm{km}^{2}$ watershed between Oregon's Cascade and Coast ranges (Fig. 1; Hulse et al., 2002). The prominent hydrologic feature of the agricultural Valley is the Willamette River and its 13 major tributaries. The Valley climate is cool Mediterranean, with an average annual rainfall of 100-125 cm, 75\% of it falling between October and March (Jackson and Kimerling, 1993). Average temperatures range from $1{ }^{\circ} \mathrm{C}$ in January to $30^{\circ} \mathrm{C}$ in July (Oregon Climate Service; www.ocs.orst.edu). The study occurred from November to March during a wet (1999-2000; $91 \mathrm{~cm}$ precipitation October-March) and a dry winter (20002001; $40 \mathrm{~cm}$ precipitation October-March; Oregon Climate Service).

Common Valley lowland crops include grass seed (most prevalent), vegetables (e.g., corn, pumpkin, bush beans, cabbage), grains, and peppermint (Hulse et al., 2002). Grass seed crops are planted in autumn, and newly planted perennial grass fields provide exposed soil between plants throughout the winter. Vegetable crops are left fallow through the winter and replanted in spring. Many of these crops are planted on what were historical wetlands and thus where soils are poorly-drained (Taft et al., 2004).

Shorebirds find accessible foraging habitat where farming practices provide exposed soil (i.e., newly planted or fallow fields). Of the 40,000 or more wintering Valley shorebird species, dunlin (Calidris alpina) and killdeer (Charadrius vociferus) are the most abundant (Sanzenbacher and Haig, 2002a,b; Taft and Haig, 2003), but common snipe (Gallinago gallinago), long-billed dowitcher (Limnodromus scolopaceus), least sandpiper (Calidris minutilla), and greater yellowlegs (Tringa melanoleuca) are also fairly common.

Invertebrates were sampled in 19 (in the wet winter) and 26 (in the dry winter) agricultural wetlands in the northeast portion of the southern Willamette Valley, a $480 \mathrm{~km}^{2}$ area of lowland plain encompassing the Calapooia River, a third to forth order tributary of the Willamette River (Fig. 1; Office 


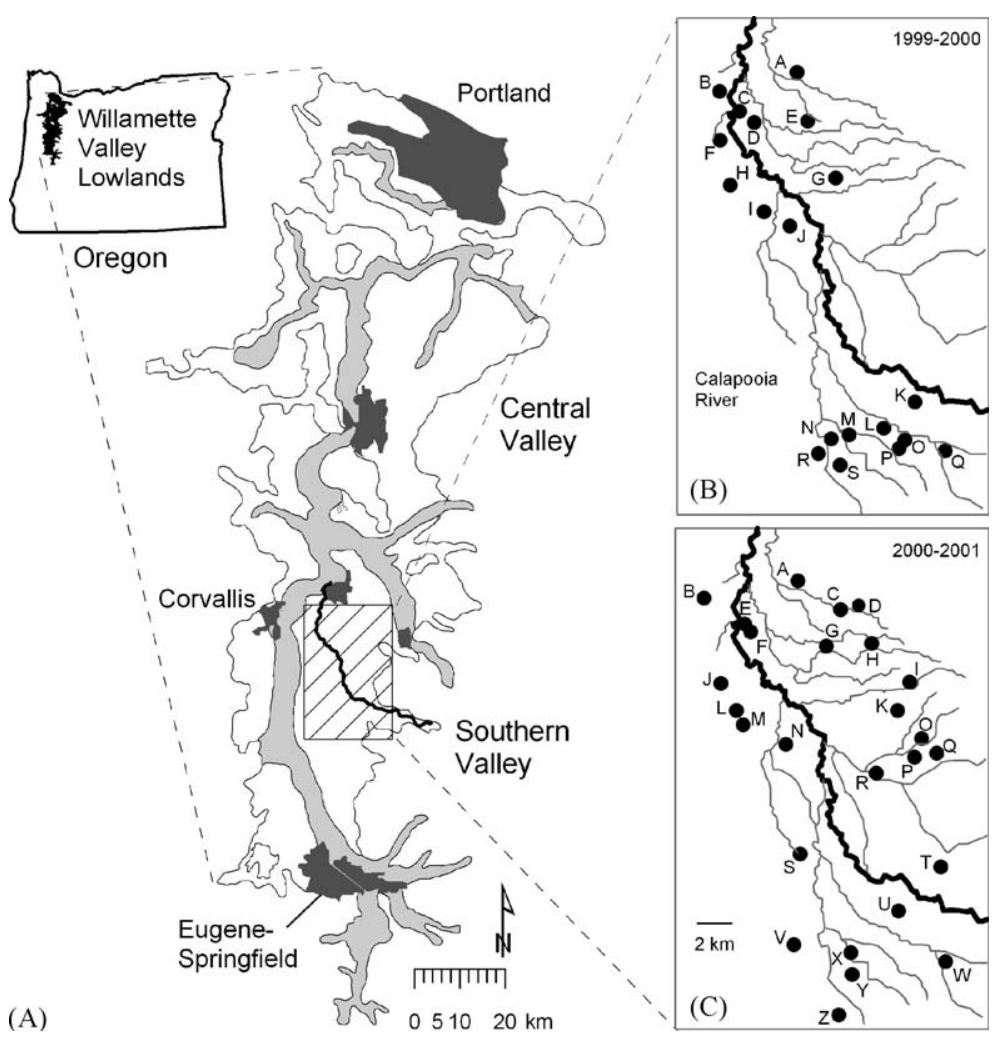

Fig. 1. Location of agricultural wetlands sampled for invertebrates mid-winter during 1999-2000 and 2000-2001 within the Willamette Valley of Oregon, USA. (A) gray: Willamette River floodplain, white: Valley alluvial terraces, dark gray: urban; (B) agricultural wetlands studied in the wet winter of 1999-2000; (C) agricultural wetlands studied in the dry winter of 2000-2001. Major streams of the Calapooia watershed shown at 1:100,000 scale (Office of Information Resources Management, 1994).

of Information Resources Management, 1994). This area is characterized by a high incidence of poorly drained hydric soils interspersed among well-drained areas (Daggett et al., 1998). Because ponding on agricultural fields tends to occur as widely scattered, irregularly shaped, changeable areas of shallow nonflowing sheetwater, entire agricultural fields were considered as sites. Among agricultural fields for which landowners permitted sampling, sites that presented accessible habitat to shorebirds were chosen, i.e., sites with shallow $(\leq 5 \mathrm{~cm})$ standing water or saturated soil, and with vegetation cover $\leq 50 \%$ throughout the winter. Sample wetlands were chosen to comprise a diversity of agricultural cover types representing proportions of the greater Valley in each [in wet winter: $72 \%$ of sites were in grass seed, $16 \%$ fallow, $5 \%$ pasture, and $5 \%$ other (wild rice pond); in dry winter: $78 \%$ of sites in grass seed, $12 \%$ fallow, $4 \%$ pasture, and $4 \%$ other (wild rice pond); J. Steiner, USDA-Agricultural Research Service, personal communication].

\subsection{Sampling and data summary}

Benthic and surface-dwelling invertebrates were sampled at each site once during mid winter: between 31 January and 15 February in 1999-2000, and between 5 January and 5 March in 2000-2001. In the wet winter, 15 core samples were collected per site at each sampling event; 30 samples were collected per site in the dry winter. Each sample was a $5-\mathrm{cm}$ diameter cylindrical core pushed $5 \mathrm{~cm}\left(98 \mathrm{~cm}^{3}\right)$ into the benthos (Sherfy et al., 2000). Invertebrates were sampled within an oblong area roughly $150 \mathrm{~m} \times 20 \mathrm{~m}$ encompassing concentrated wet areas of sites. Within sample areas, one core was systematically collected 
every $10 \pm 2 \mathrm{~m}$ along a linear zig-zagging transect. Half of all core samples at each site were collected in flooded habitat (less than $5 \mathrm{~cm}$ deep) and half in nonflooded but moist/saturated habitat.

Samples were washed, sieved (500 $\mu \mathrm{m}$ mesh) and preserved in $70 \%$ ethanol solution within 2 days of collecting (kept refrigerated until sieved and fixed). Using a stereomicroscope at $30 \times$, observers sorted through sieved debris and identified, counted, and collected all invertebrates of taxonomic groups that have been documented in shorebird diets (Skagen and Oman, 1996). Pennak (1978) and Merrit and Cummins (1984) were used to identify invertebrates to the level of family for Oligochaeta (Enchitraeidae, Tubificidae, Lumbricidae) and most Insecta larvae (Chironomidae, Empididae, Tipulidae), but ostracods (Ostracoda) were identified only to subclass, and haplotaxid worms (Haplotaxida), springtails (Collembola), and caddisfly larvae (Trichoptera) only to taxonomic order. Although shorebirds have been known to take invertebrates (e.g., ostracods) as small as $1.0 \mathrm{~mm}$ long (Weber and Haig, 1997), nektonic (i.e., ostracods) and mobile small invertebrates (i.e., springtails) were not adequately sampled and consequently excluded from abundance measures. Information on presence/ absence of these groups is presented.

Because the body size of individuals of each identified group appeared to vary little among sites and between years, dry biomass estimates were obtained by drying at $50{ }^{\circ} \mathrm{C}$ for $24 \mathrm{~h}$, and weighing to nearest $0.0001 \mathrm{~g}$ a variable collection (i.e., some small, some large) of individuals of each group from all sites studied in 2000-2001 (360 small oligochaetes, 50 lumbricids, 38 chironomids, 10 empids, 23 tipulids and 20 trichoptera). The total biomass for each group was then divided by the number of collected individuals to generate average biomass multipliers which were then used in conjunction with counts of individuals to calculate estimated total biomass of each core sample.

Data were summarized for the following numerically dominant taxonomic groups: (1) Aquatic oligochaetes (small-bodied aquatic worms in the order Haplotaxida and families Enchitraeidae and Tubificidae), (2) Megadrili (large-bodied oligochaetes primarily in the family Lumbricidae), (3) Chironomidae, (4) Empididae, (5) Tipulidae, and (6) Trichoptera. Two measures describing the total abundance of these six taxonomic groups at each site were generated: (1) invertebrate density (individuals/ $\mathrm{m}^{2}$ ), calculated as the mean number of invertebrates among collected core samples, and (2) invertebrate biomass $\left(\mathrm{mg} / \mathrm{m}^{2}\right)$, calculated as the mean estimated dry biomass of invertebrates among cores. Differences among sites in log (natural)-transformed invertebrate density and invertebrate biomass were assessed using one-way analysis of variance and multiple comparisons among site biomass estimates were made using Bonferroni $t$-tests ( $t$ probability/number of comparisons; Ramsey and Schafer, 1997). To assess general trends in community composition, invertebrate densities of each taxonomic group are presented.

\section{Results}

In the wet winter of 1999-2000, wetland sites varied in invertebrate density from $173 \pm 53$ (mean \pm S.E. among cores) to $1925 \pm 428$ individuals $/ \mathrm{m}^{2}$, and in estimated invertebrate biomass from $35 \pm 11$ to $652 \pm 234 \mathrm{mg} / \mathrm{m}^{2}$ (Fig. 2). Among sites during the dry winter of 2000-2001, density varied from $214 \pm 45$ to $3484 \pm 416$ individuals $/ \mathrm{m}^{2}$, and estimated biomass from $85 \pm 24$ to $1405 \pm 226 \mathrm{mg} / \mathrm{m}^{2}$ (Fig. 3). In both winters, sites differed significantly in total invertebrate density (wet winter: $F_{18,266}=2.94, P<0.001$; dry winter: $\left.F_{25,752}=9.17, P<0.001\right)$ and total estimated invertebrate biomass (dry winter: $F_{18,266}=2.30$, $P<0.01$; dry winter: $\left.F_{25,752}=9.00, P<0.001\right)$. Multiple comparisons indicate there were more differences in biomass estimates among sites in the dry winter (Fig. 3) compared to the wet winter (Fig. 2). However, averaged among all sites, measures for total invertebrate density and estimated biomass were similar among years, with mean \pm S.E. of $936 \pm 106$ (wet winter) and $1028 \pm 155$ (dry winter) individuals $/ \mathrm{m}^{2}$ for density (Table 1 ), and $364 \pm 35$ (wet winter) and $437 \pm 62$ (dry winter) $\mathrm{mg} / \mathrm{m}^{2}$ for estimated biomass. In general, given error (i.e., S.E. around the site mean) in invertebrate abundance of wetlands, most sites could be considered fairly close to the among-site average in both years.

Although community composition varied among sites, most wetlands were dominated by aquatic oligochaetes, which accounted for on average 82\% (wet winter) and $80 \%$ (dry winter) of total invertebrate 


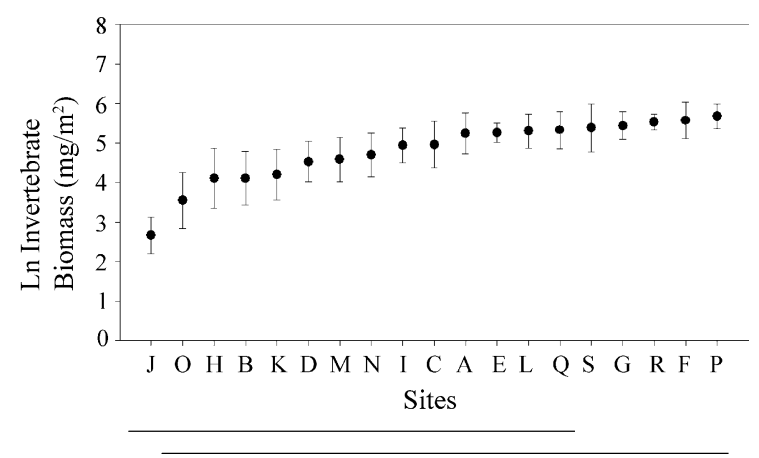

Fig. 2. Mean ( \pm S.E.) of log (natural)-transformed total invertebrate estimated biomass $\left(\mathrm{mg} / \mathrm{m}^{2}\right)$ at 19 sites sampled for benthic invertebrate abundance in the Willamette Valley of Oregon during the wet winter of 1999-2000. Lines below bar chart $x$-axes signify groups of similar sites in biomass. Site means spanned by the same line are not significantly different as evaluated using Bonferroni $t$-tests for multiple comparisons after one-way ANOVA. See Fig. 1 for locations of sites.

communities (Table 1). For the most part, empids, tipulids, and trichoptera accounted for a minority of communities. However, for a few sites, megadrili (e.g., site $\mathrm{H}$ in the wet winter; sites $\mathrm{U}$ and $\mathrm{C}$ in the dry winter), chironomids (e.g., site $\mathrm{S}$ in the wet winter; sites $\mathrm{I}$ and $\mathrm{U}$ in the dry winter), tipulids (e.g., site B in the wet winter) or trichoptera (e.g., site $\mathrm{M}$ in the wet winter; sites $\mathrm{J}$ and $\mathrm{V}$ in the dry winter) represented relatively significant proportions of communities (e.g., $25 \%$ of total invertebrate density or more). Collembola were present in 10 out of $19(53 \%)$ sites in the wet winter, and 14 of $26(54 \%)$ sites in the dry winter. Ostracods were less common, observed in 5 of 19

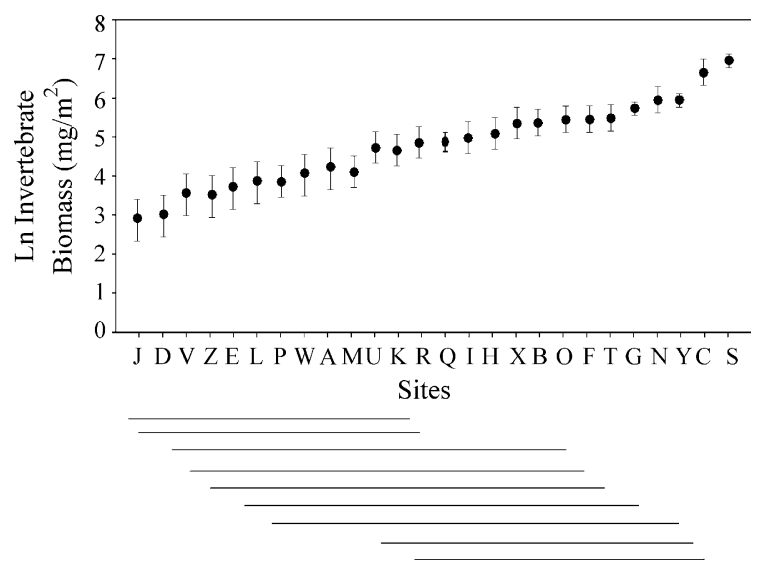

Fig. 3. Mean ( \pm S.E.) of $\log$ (natural)-transformed total invertebrate estimated biomass $\left(\mathrm{mg} / \mathrm{m}^{2}\right)$ at 26 sites sampled for benthic invertebrate abundance in the Willamette Valley of Oregon during the dry winter of 2000-2001. Lines below bar chart $x$-axes signify groups of similar sites in biomass. Site means spanned by the same line are not significantly different as evaluated using Bonferroni $t$-tests for multiple comparisons after one-way ANOVA. See Fig. 1 for locations of sites.

$(26 \%)$ and 8 of $26(31 \%)$ sites in the wet winter and dry winter, respectively.

\section{Discussion}

Compared to estimates of invertebrate abundance at inland stopovers in spring and fall (e.g., Farmer and Wiens, 1999; Augustin et al., 1999; Ashley et al., 2000), abundances of winter shorebird food among

Table 1

Average ( \pm S.E. among sites) mean (among cores at each site) densities (individuals $/ \mathrm{m}^{2}$ ) and community composition (average proportions of total invertebrate density among sites) for taxonomic groups observed at 19 (wet winter of 1999-2000) and 26 (dry winter of 2000-2001) sites in the Willamette Valley of Oregon, USA

\begin{tabular}{|c|c|c|c|c|}
\hline \multirow[t]{2}{*}{ Taxonomic group } & \multicolumn{2}{|l|}{ Wet winter } & \multicolumn{2}{|l|}{ Dry winter } \\
\hline & Density & Proportion of total $^{c}$ & Density & Proportion of total \\
\hline Aquatic oligochaetes $^{\mathrm{a}}$ & $820 \pm 112$ & $82 \pm 4$ & $877 \pm 145$ & $80 \pm 3$ \\
\hline Megadrili $^{\text {b }}$ & $42 \pm 16$ & $6 \pm 3$ & $61 \pm 19$ & $8 \pm 2$ \\
\hline Chironomidae & $32 \pm 11$ & $5 \pm 2$ & $45 \pm 13$ & $6 \pm 2$ \\
\hline Empididae & $8 \pm 3$ & $1 \pm 1$ & $28 \pm 14$ & $3 \pm 1$ \\
\hline Tipulidae & $26 \pm 8$ & $5 \pm 3$ & $4 \pm 1$ & $1 \pm<1$ \\
\hline Trichoptera & $9 \pm 3$ & $4 \pm 3$ & $12 \pm 6$ & $3 \pm 2$ \\
\hline Total invertebrates & $936 \pm 106$ & - & $1028 \pm 155$ & - \\
\hline
\end{tabular}

\footnotetext{
${ }^{\text {a }}$ Small-bodied worms in the order Haplotaxida and families Enchitraeidae and Tubificidae.

b Large-bodied oligochaetes, primarily in family Lumbricidae.

${ }^{c}$ Proportion of the density of all tallied invertebrates at each site.
} 
agricultural wetlands of the Valley were relatively low. However, Valley estimates were comparable to the lower end of the range of estimates observed during winter in other significant freshwater wintering regions. Moreover, abundance estimates were similar among the 2 years studied, implying that the densities and biomasses observed might be reliable assessments of the typical abundance of invertebrates provided by wetlands in any given year. Valley estimates were comparable to winter invertebrate abundances observed among brackish managed wetlands in South Carolina (Weber and Haig, 1996) where densities range from approximately 250 to 3800 individuals $/ \mathrm{m}^{2}$ and biomass from 250 to $500 \mathrm{mg} / \mathrm{m}^{2}$. In moist-soil managed playa wetlands of the Southern High Plains of Texas, Anderson and Smith (2000) estimated mean winter total invertebrate (96\% benthic) densities among wetlands of only 155 individuals $/ \mathrm{m}^{2}$, but owing to greater presence of large-bodied invertebrates in this locale, mean total invertebrate biomass estimates (i.e., $3522 \mathrm{mg} / \mathrm{m}^{2}$ ) were higher than in the Valley. Among winter wetlands in the Sacramento Valley of California, Elphick (2000) estimated average densities of roughly 2500 individuals $/ \mathrm{m}^{2}$ among flooded rice fields and approximately 5500 individuals $/ \mathrm{m}^{2}$ among seminatural wetlands. Finally, moist-soil managed wetlands of the Suisun Marsh (Batzer et al., 1997) and San Joaquin Valley of California (Safran et al., 1997) were highly productive, with high biomass estimates (e.g., on average about $400-1900 \mathrm{mg} / \mathrm{m}^{2}$ among foraging sites of five shorebird species; Safran et al., 1997) and densities (individuals $/ \mathrm{m}^{2}$ ) of chironomids (Batzer et al., 1997) and small oligochaetes (Safran et al., 1997) in the tens of thousands. Although Valley sites may have been sampled after shorebirds had depleted prey and deflated estimates of abundance relative to other locales, the confounding influence of prey depletion was a concern among these other studies as well.

Valley wetlands differed relatively little in invertebrate density and estimated biomass, especially in the wet winter of 1999-2000 (Table 1; Fig. 2). Such low variation may have been due to the fact that fields were sampled after birds had preferentially foraged at the most productive sites, depleting resources to comparable levels observed at less productive sites. Alternatively, during normal years for rainfall, invertebrate productivity may in fact be similar across agricultural wetlands. Given there are hundreds of agricultural wetlands in the Valley (Taft et al., 2004), even if each individual wetland only offered a low to moderate abundance of food, sites of this region may collectively provide a notable invertebrate prey base for shorebirds and other waterbirds.

Invertebrate abundances varied more among sites during the dry winter of 2000-2001, and some tentative explanations may be presented for this. Mean minimum and maximum temperatures were no different between winters (Oregon Climate Service data 1999-2001) discounting the possibility that some sites produced more invertebrates in the dry winter from increased temperatures influencing the vertical distribution of prey or the rate of decomposition of organic matter (e.g., Fredrickson and Laubhan, 1994; Durell, 2000). However, during the dry winter, there may have been greater variation in soil saturation/wetness of sites and thus in the conditions promoting invertebrate production. Moreover, fewer dunlin were observed at dry winter sites (Taft and Haig, in press) and thus invertebrates at the most productive sites may not have received the same predation pressure as in the wet winter.

Agricultural wetlands were dominated numerically by aquatic oligochaetes in both winters, with earthworms (megadrils) and chironomids comprising the majority of the remaining community of most sites (Table 1). Such composition contrasts that found in other important wintering wetland locales, namely California moist-soil managed wetlands where chironomids numerically dominate invertebrate communities (Batzer et al., 1997; Safran et al., 1997). However, caloric content values do not differ greatly between Oligochaeta and Chironomidae (Cummins and Wuycheck, 1971). Thus, all else being equal, oligochaete-dominated communities may provide energetic benefits that are equivalent to those provided by chironomid-dominated communities. Earthworms are common in agricultural lands (Tucker, 1992; Ausden et al., 2001), and were present at most Valley sites in similar densities to those observed in coastal California pastures used by wintering shorebirds (32176 individuals $/ \mathrm{m}^{2}$; Colwell and Dodd, 1995; Table 1). Moreover, their contribution to biomass was high in those agricultural wetlands where they were relatively abundant. Earthworms are commonly consumed by plovers (Charadrius species; e.g., 
Bengtson et al., 1978; Barnard and Thompson, 1985; Jackson and Jackson, 2000) and other waders (Ausden et al., 2001), and dunlin were observed eating earthworms on a number of occasions during the present study. Earthworms of Valley agricultural wetlands are likely an important resource for wintering shorebirds.

Left in farming, it seems that Valley agricultural wetlands at least have the capacity to produce shorebird food at abundance levels comparable to those sites observed with the greatest abundance of invertebrates (i.e., $\sim 3000$ individuals $/ \mathrm{m}^{2} ; 1500 \mathrm{mg}$ / $\mathrm{m}^{2}$ ). Moreover, active restoration and enhancement of these wetlands and ongoing management of their vegetation and hydrology may boost invertebrate abundances even above these levels. However, even while maximizing such factors contributing to productivity, the relatively cold temperatures of the Valley may impose an upper bound on the potential productivity of invertebrates.

\section{Acknowledgements}

We are indebted to J. Dhundale, M. Henschen, W. Jensen, and H. Packard for their help in collecting invertebrate samples, and to W. Jensen, R. Moran, and H. Packard for sorting hundreds of samples in the lab. We also thank J. Beall, K. Bierly, M. Colwell, R. Goggans, J. Morlan, M. Naughton, P. Sanzenbacher, C. Schuler, S. Smith, B. Taylor, and T. Zimmerman for advice, technical and logistical assistance. This work benefited greatly from discussions with G. Bradshaw, W. Gerth, J. Hayes, R. Hoffman, W. Hohman, M. Huso, L. Oring, P. Sanzenbacher, N. Schumaker, J. Steiner, and L. Weber. Project funding was generously provided by the USGS Forest and Rangeland Ecosystem Science Center, U.S. Fish and Wildlife Service, Oregon Department of Fish and Wildlife, Oregon Watershed Enhancement Board, and Bureau of Land Management.

\section{References}

Anderson, J.T., Smith, L.M., 1999. Carrying capacity and diel use of managed playa wetlands by nonbreeding waterbirds. Wildl. Soc. Bull. 27, 281-291.
Anderson, J.T., Smith, L.M., 2000. Invertebrate responses to moistsoil management of playa wetlands. Ecol. Appl. 10, 550558.

Ashley, M.C., Robinson, J.A., Oring, L.W., Vinyard, G.A., 2000. Dipteran standing stock biomass and effects of aquatic bird predation at a constructed wetland. Wetlands 20, 84-90.

Augustin, J.C., Grubaugh, J.W., Marshall, M.R., 1999. Validating macroinvertebrate assumptions of the shorebird management model for the lower Mississippi Valley. Wildl. Soc. Bull. 27, 552-558.

Ausden, M., Sutherland, W.J., James, R., 2001. The effects of flooding lowland wet grassland on soil macroinvertebrate prey of breeding wading birds. J. Appl. Ecol. 38, 320-338.

Barnard, C.J., Thompson, D.B.A., 1985. Gulls and plovers: The ecology and behavior of mixed-species feeding groups. Columbia University Press, New York, NY.

Batzer, D.P., de Szalay, F., Resh, V.H., 1997. Opportunistic response of a benthic midge (diptera: Chironomidae) to management of California seasonal wetlands. Environ. Ent. 26, 215-222.

Bengtson, S., Rundgren, S., Nilsson, A., Nordström, S., 1978. Selective predation on lumbricids by golden plover Pluvialis apricaria. Oikos 31, 164-168.

Benner, P.A., Sedell, J.R., 1997. Upper Willamette River landscape: a historic perspective. In: Laenen, A., Dunnette, D.A. (Eds.), River Quality: Dynamics and Restoration. Lewis Publishers, New York, NY, pp. 23-47.

Brown, S., Hickey, C., Harrington, B., Gill, R., 2001. The U.S. Shorebird Conservation Plan, second ed. Manomet Center for Conservation Sciences, Manomet, MA.

Clark, S.E., White, D., Schaedel, A.L., 1991. Oregon, USA, ecological regions and subregions for water quality management. Environ. Manage. 15, 847-856.

Colwell, M.A., Dodd, S.L., 1995. Waterbird communities and habitat relationships in coastal pastures of Northern California. Conserv. Biol. 9, 827-834.

Cowardin, L.M., Carter, V., Golet, F.C., LaRoe, E.T., 1979. Classification of Wetlands and Deepwater Habitats of the United States. U.S. Fish and Wildlife Service, Washington, DC.

Cummins, K.W., Wuycheck, J.C., 1971. Caloric Equivalents for Investigations in Ecological Energetics. Internationale Vereinigung fur Theoretische und Angewandte Limnologie No. 18, Stuttgart, Germany.

Daggett, S.G., Boulé, M.E., Bernert, J.A., Eilers, J.M., Blok, E., Peters, D., Morlan, J., 1998. Wetland and land use changes in the Willamette Valley, Oregon: 1982 to 1994. Report to the Oregon Division of State Lands, Shapiro and Associates, Inc., Portland, OR.

Durell, S.E.A.leV.dit, 2000. Individual feeding specialization in shorebirds: population consequences and conservation implications. Biol. Rev. 75, 503-518.

Elphick, C.S., 2000. Functional equivalency between rice fields and seminatural wetland habitats. Conserv. Biol. 14, 181-191.

Elphick, C.S., Oring, L.W., 1998. Winter management of Californian rice fields for waterbirds. J. Appl. Ecol. 35, 95-108.

Elphick, C.S., Oring, L.W., 2003. Conservation implications of flooding rice fields on winter waterbird communities. Agric. Ecosyst. Environ. 94, 17-29. 
Farmer, A.H., Wiens, J.A., 1999. Models and reality: time energy trade-offs in pectoral sandpiper (Calidris melanotos) migration. Ecology 80, 2566-2580.

Fasola, M., Ruiz, X., 1997. Rice farming and waterbirds: integrated management in an artificial landscape. In: Pain, D.J., Pienkowski, M.W. (Eds.), Farming and Birds in Europe: the Common Agricultural Policy and its Implications for Bird Conservation. Academic Press, San Diego, CA, pp. 210-235.

Fredrickson, L.H., Laubhan, M.K., 1994. Managing wetlands for wildlife. In: Bookhout, T.A. (Ed.), Research and Management Techniques for Wildlife and Habitats. The Wildlife Society, Bethesda, MD, pp. 623-647.

Hulse, D., Gregory, S., Baker, J., 2002. Willamette River Basin Planning Atlas: Trajectories of Environmental and Ecological Change. Edited for the Pacific Northwest Ecosystem Research Consortium. Oregon State University Press, Corvallis, OR.

Jackson, B.J.S., Jackson, J.A., 2000. Killdeer (Charadrius vociferus). In: Poole, A., Gill, F. (Eds.), The Birds of North America, vol. 517. The Birds of North America Inc., Philadelphia, PA.

Jackson, P.L., Kimerling, A.J., 1993. Atlas of the Pacific Northwest. Oregon State University Press, Corvallis, OR.

Merrit, R.W., Cummins, K.W., 1984. An Introduction to the Aquatic Insects of North America, second ed. Kendall/Hunt Publishing Company, Dubuque, IA.

Myers, J.P., Morrison, R.I.G., Antas, P.Z., Harrington, B.A., Lovejoy, T.E., Sallaberry, M., Senner, S.E., Tarak, A., 1987. Conservation strategy for migratory species. Am. Sci. 75, 19-26.

Nehls, H.B., 1994. Oregon Shorebirds: their Status and Movements. Technical Report 94-1-02, Wildlife Diversity Program. Oregon Department of Fish and Wildlife, Portland, OR.

Office of Information Resources Management, 1994. Pacific Northwest (PNW) 1:100,000 River Reach File System, version 2.1. Pacific States Marine Fisheries Service, US Geological Survey, Environmental Protection Agency, Washington, DC.

Pennak, R.W., 1978. Freshwater Invertebrates of the United States, third ed. John Wiley and Sons, New York, NY.

Ramsey, F.L., Schafer, D.W., 1997. The Statistical Sleuth: A Course in Methods of Data Analysis. Wadsworth Publishing Company, Belmont, CA.
Safran, R.J., Isola, C.R., Colwell, M.A., Williams, O.E., 1997. Benthic invertebrates at foraging locations of nine waterbird species in managed wetlands of the northern San Joaquin Valley, California. Wetlands 17, 407-415.

Sanzenbacher, P.M., Haig, S.M., 2002a. Residency and movement patterns of wintering Dunlin in the Willamette Valley of Oregon. Condor 104, 271-280.

Sanzenbacher, P.M., Haig, S.M., 2002b. Regional fidelity and movement patterns of wintering Killdeer in an agricultural landscape. Waterbirds 25, 16-25.

Senner, S.E., Howe, M.A., 1984. Conservation of nearctic shorebirds. In: Burger, J., Olla, B. (Eds.), Shorebirds: Breeding Behavior and Populations. Plenum Press, New York, NY, pp. 379-421.

Sherfy, M.H., Kirkpatrick, R.L., Richkus, K.D., 2000. Benthos core sampling and chironomid vertical distribution: implications for assessing shorebird food availability. Wildl. Soc. Bull. 28, 124130.

Skagen, S.K., Oman, H.D., 1996. Dietary flexibility of shorebirds in the western hemisphere. Can. Field-Nat. 110, 419-444.

Taft, O.W., Haig, S.M., 2003. Historical wetlands in Oregon's Willamette Valley: implications for restoration of winter waterbird habitat. Wetlands 23, 51-64.

Taft, O.W., Haig, S.M., Kiilsgaard, C., 2004. Use of radar remote sensing (RADARSAT) to map winter wetland habitat for shorebirds in an agricultural landscape. Environ. Manage. 33, 750-763.

Taft, O.W., Haig, S.M., in press. Importance of wetland landscape structure to shorebirds wintering in an agricultural valley. Landscape Ecol.

Tucker, G.M., 1992. Effects of agricultural practices on field use by invertebrate-feeding birds in winter. J. Appl. Ecol. 29, 779-790.

Twedt, D.J., Nelms, C.O., Rettig, V.E., Aycock, S.R., 1998. Shorebird use of managed wetlands in the Mississippi Alluvial Valley. Am. Midl. Nat. 140, 140-152.

Weber, L.M., Haig, S.M., 1996. Shorebird use of South Carolina managed and natural coastal wetlands. J. Wildl. Manage. 60, 7382.

Weber, L.M., Haig, S.M., 1997. Shorebird-prey interactions in South Carolina coastal soft sediments. Can. J. Zool. 75, 245-252. 